\title{
A STUDY OF THE VESTIBULAR NUCLEI
}

\author{
By \\ KENDO NOGUCHI \\ From the Department of Oto-Rhino-Laryngology, Juntendo University. \\ School of Medicine. (Director: T. Ishikura, M.D.)
}

To clarify the function of the vestibular nuclei an experimental study was made. Nystagmic responses of the cats were observed when the unilateral vestibular nuclei were stimulated electrically.

And then the point having responded to electrical stimulation was coagulated. Spontaneous and positioning nystagmus was observed. After the experiment, the animal was killed and its brain was removed in order to examine the coagulated point histologically.

The following results were obtained:

1) Relation between electrical stimulation to the vestibular nuclei and nystagmic responses:

When an optional point of the vestibular nucleus out of four vestibular nuclei (nucleus medialis, nucleus dorsalis, nucleus spinalis, nucleus lateralis.) was electrically stimulated, a type of nystagmic response was observed. On the other hand, when a certain point of other vestibular nucleus was electrically stimulated, the same type of nystagmic response was noticed. For example, horizontal nystagmus was caused not only by stimulation to the nucleus dorsalis, but also by stimulation to the nucleus lateralis.

2) Positioning nystagmus:

Positioning nystagmus had latency period of 1 to 2 sec., and continued a few seconds, and then disappeared.

Nystagmus caused by electrical stimulation had a tendency to be influenced by head positioning. Moreover, horizontal nystagmus was much influenced when the head was suddenly turned to the right side or left.

On the other hand, vertical nystagmus was also done when the head was turned around the sagittal plane.

\section{前庭核に対する電気剌激的研究}

\author{
（前庭核刺激と眼振について）
}

順天堂大学医学部耳咸咽堠科学教室（主任：石会武焳教授）

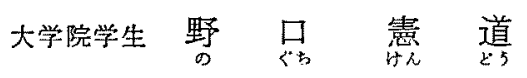
目次
I 緒言
I1. 实験動物及び実験方法
目. 実験成絽
N. 考按並びに総括
1. 水平性腿振について
2. 墡直性服振について
3. 迴旋性腿振について
4. 期性眼振について
5. 電気刺激時眼振と電気潪固後の自発服振につ いて
6. 頭位变换限振について
V 結語
I. 緒 言
前庭核と眼球振盪との関係について現在まで幾多の報 告があるが，各報告者の説は種々まちまちで定説がな く, 又その経路についても明確な回答が得られていな い.な和多くの未解決の分野が残つている. 
前庭㤥の機能火阙与る㖄究を振返ると，主なるのは， Marburg (1912), Leidler (1913, 1916), Gray (1926), Spiegel, Sato (1927), 高橋 (1931), 大和田 (1948), Cranmer (1951), 阿部 (1960), Bergmann, Lachmann, Monnier (1960), Carpenter, Alling, Bard (1960), Montandon (1964) 等の報告があるが，外側核を損傷 した場合 Marburg, Leidler, Cranmer 等水平性眼 振，松下 (1938) 㳊垂直性眼振，Spiegel Sato は垂直 性腿振㕛は水平性腿振，Crosby (1953)"は垂直性眼振又 は斜性眼振が発現すると述べ，Montandonは外側核は 眼振発現に関与しない之論じた. 又，眼振の方向につい て，Cranmer 江外側核を刺激した場合には術側向水平 性眼振，破壊した場合には侓側向水平性眼振が発現する と報告し，それを両侧の前庭核間の不均衡しより説明し ているが，Montandon は刺激で名破壊でも眼振の方向 は変化せ欢と述べている。内海は刺激の強さとより，

Eye Deviation, Nystagmus, Tetanic eye-deviation が反応として現われると述べている。

以上の報告に上り，各前莛核と各種眼振との関保を追 求する目的で，以下の契験を試みた。

\section{II. 実験動物及ひ実験方法}

実験材料には前庭系に機能障害のない2〜3kg 位の 成熟猎を用いた。

1. 前庭核の刺激及び電気筑固

成熟猫をエーテルにて麻酔し, 東大脳研式脳定位固定 装置化腹位に固定し，頭頂部より後頭部にかけて正中線 にメスを入れ，筋肉を左右に分け頭蓋骨を露出せしめ， 左側の頭頂, 後頭骨を開頭す次で脳硬膜を開き, 脳表 より Magnus の脳定位座整図を指針とし前庭核の部に 電極を㨉入した．術側はすべて左側とした。

刺激方法は，日本光電製 MSE- 目型を用い，刺激電 極は 0.5 又は $0.8 \mathrm{~mm}$ 直径の同心双極電極を用い，刺激 電王は 2 ボルト。刺激は3〜7サイルの矩形波とて行 なつた。

電気刺激により眼振の有無を因眼的に観察し，刺激に 上り確実な眼振が発現した時に, 眼振性状を詳細に観察 し，その後刺激電極に 30 ボルト 30 秒淔流通電により， その部を電気凝固した。

このらちの数例に执いて猫を 固定装置に 固定したま ま，健側下位，術側下位，頭上位，尾上位の四方向体 位を変換せしめ，又それぞれの変换位より元の体位に復 帰让しめて, 頭位变換に上る眼振の変化, 即ち頭位変換 眼振を観察した。

\section{2. 刺激部位の判定}

刺激实験，電気㠜圆後，脳を摘出し，ミューラー氏倠 固定, ツェロイジン包埋, $20 \mu$ の完全連続切片を作成 し，パールロイダルト．カルミン染色を行い，又ある例 では湅結切片を作成し，Klüver-Barrera 染色を行い，

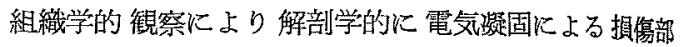
位を決定した，病理所見䛱，組織融甥像，小出血菓，

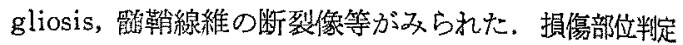
に関しては，本学第二解部学䀅田栄教授の御指導定心た 炑き，又 Taber (1961)，肾玉の四等を参考とした， 前庭核住一般的な分類に良い，1）内側核（三角核，シ ユワルベ氏核)2）外側核（ダイテルス氏核）背側核 (隅核，ベヒテレフ氏核）4）下行路核に分類した.

\section{III. 実験 成 績}

実験例は 28 例であるが，手術中死亡，腿振が不確实 なもの等を除外し，詳細に観察することの出きた 16 例 につき記述する。

No. $2, \quad 33.0 \mathrm{~kg}$

1. 刺激実嚳

刺激時の眼振は雨眼共大きさの等しい時計針力向の䞤 损性眼振が発現した。

\section{2. 電笑㠜固後の観察}

電気凝固後は両眼上も自発眼振は観察されなかつた。

3. 組織学的钼察 (図 1)

損甥部位は，舌下神経核の上部に相当する高さで，前 庭神経下行路核の下部が活とんぞ損傷を受け，その他三

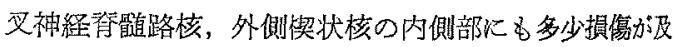
んでいた.

No. $3, \quad$ \% $1.8 \mathrm{~kg}$

この症例において，実験中室内の照明が明る過ざると 眼振が小さくなり，又停止するといら現象が起る事を 知り，以後は眼振の観察に必要な程度の明るさに止め た。

1. 刺激実驗

刺激時両眼共著明な水平性眼振を生じた。

2. 組織学的観察 (図 2)

損賃部位は，舌下神絽核上部の高さで，前庭神経下行 路核の外側部及び三叉神絽脊蹈路核のごくわずかの部を 破壦していた。

No. 4 , of $3.0 \mathrm{~kg}$

1. 刺激䒠鈳

刺激時は健側向水平性眼振が出現した。 


\section{2. 電気凝固実験}

上記健側向水平坐眼振が出現した 部を電気凝固する と, 電気凝固中眼球が健側に変位していた。

3. 電気勰固後の観察

電気凝固後, 眼振は観察されなからた。

4. 組織学的観察 (図 3 )

電気凝固による損傷は，舌下神経核の最上部の高さ で，前庭神絽下行路核の腹外側部に存在した。

No. $5, \quad$ o $3.0 \mathrm{~kg}$

1. 刺激実験

刺激時の眼振は，健側向水平性眼振が発現した。

2. 電気凝固実鎹

䉓気凝固時，術側に眼球が変位していた。

3. 電気凝固後の観察

電気凝固後は健側向水平性自発眼振が観察された。こ の例は電気凝固後 20 時間生存させたが，この自発眼振 に変化はみられなかつた。

頭位变換眼振は，電気凝固後 15 分， 12 時間の 2 回蕉 察した，術側下位への変換で，変换後約 2 秒で自発眼振 の大ささが著明に增強され，䄪 10 秒後もとの眼振にも どる. 術側下位よりの復弯時には，自発眼振に変化は認 めら机かかた，健側下位への変換では，変換後約 2 秒 で自発眼振は抑制され眼振の大きさが小さくなり，約 10 秒後もとの 自発眼振となる. 復㷌時には自発眼振に 変化は認められなからた．頭上位，尾上位への变換・復 帏位にては，自発眼振に変化梕められなからた。なお 頭位変換眼振の観察において，2 回之も前記の現象が観 察された。

4. 組織学的観察 (図 4)

損傷部位は，顔面神経核の高さで，前莛神経下行路核 の腹外側部，及び三叉神経脊䪔路核を大きく損傷してい た.

No. $6, \quad+3.0 \mathrm{~kg}$

1, 刺激䨋験

刺激眭は，両眼共術側向水平性眼振が発現したが，健 側 (右眼) の眼振の大きさが術側 (左眼) の眼振より大 きからた。

\section{2. 電気凝固後の観察}

笔気㠜固後の自発眼振は両眼共大きさの等しい術側向 水平性眼振が発現している.

3. 組織学的観察 (図 5)

損傷部位は，舌下神経核上部の高さに相当し，前庭神
経下行路核の最下部がほとしど損傷を受けている。

No. $7, \quad$ ○ $3.0 \mathrm{~kg}$

1. 刺激実験

刺激時の眼振は，術側向水可性眼振が発現した。

2. 組織学的観察 (図6)

損傷部位は，三叉神経運洏核の高さに相当し，前庭神 経背側核の最上部の中央であった。

No. $8, \quad \delta 2.0 \mathrm{~kg}$

1. 刺激実験

刺激時の眼振は, 術側向水平性眼振が発現した．

2. 組織学的钼察 (図 7)

椇傷部位は，三文神経運動核の高さに相当して, 前庭 神経背側核の最上部の外側であつた。

No. 9 , क $2.0 \mathrm{~kg}$

1. 刺激実験

刺激時は，健側向水平性眼振が発現した。

2, 電気凝固後の钼察

電気凝固後, 眼振の発現は認められなかつた。

3. 組織学的観察 (図 8)

損傷部位は，顔面神経陵状部の高さに相当して，前庭 神経外側核の外側部及び三叉神経脊婹路核の一部であつ た.

No. $11, \quad \delta \quad 2.7 \mathrm{~kg}$

1. 刺激実験

刺激時の眼振は上向性垂直性眼振が発現した。

2. 組織学的観察 (図 9)

損傷部位は，三叉神経運動核の高さに相当して，前庭 神経背側核の外側の一部が少し損傷されていた。

No. 13 , क $2.3 \mathrm{~kg}$

1. 刺激実験

刺激時の眼振は, 上向性垂直性眼振が観察された。

2. 組織学的観察 (図 10)

損甥部位は，顔面神経核の高さに相当して，前庭神経 下行路核の上部の腹側部及び三叉神経全髓路核の一部で あつた。

No. $15, \quad$ o $2.2 \mathrm{~kg}$

1. 刺激实験

刺激時の眼振は，両眼共上向性垂直性眼振が観察され た.

2. 組織学的観察 (因 11)

損傷部位は，顔面神絟㯲状部の高さに相当して，前庭 神経内側核の腹側部が少しく損稘されていた。 
No. $19, \quad$ \& $3.1 \mathrm{~kg}$

1. 刺激 实験

刺激時は两眼共健側向水平性 眼振が発現した。 その 際，健側の眼振は術側の腿振より振幅がやや大であつ た.

\section{2. 電気凝圆実験}

電気凝固時には眼振の発現及び眼球变位はみられなか つた.

\section{3. 電気凝固後の観察}

電気㠜固後汇，自発眼振㤝発現しなかつた。

頭位变換眼振は，術側下位への变換では眼振の発現は ないが，復帰させると小さな健側向水平性眼振が発現す る. 健側下位への变換でる眼振は起ら炇が，元の体位に 復帰さ好ると，約 1 秒の潜伏期の後化術側向水平性眼振 が7〜8 回発現する。なお，開頭後で刺激実験前比頭位 変换を行うも, 術側下位, 促側下位, 䌿上位, 尾上位, 及びそれぞれの復帰位にて，いずれも眼振の発現はなか つた.

4. 組織学的観察 (図 12)

損傷部位は，舌下神経核上部の高さに相当して，前莛 神経下行路核の下部の背外側部であつた。

No. $20, \% 2.6 \mathrm{~kg}$

1. 刺激寒戨

刺激時の眼振は，両眼共振偪の等しい上向性垂直性眼 振が観察された。

\section{2. 霝気凝固実験}

電気政固時には眼振及び眼球变位は発現しなからた。

3. 電気凝固後の観察

電気凝固後, 自発眼振の発現は認められなからた。

頭位変換に批いて，術側下位及びその復帰，健側下位 及び復归の各々に心いて，眼振の発現はなかつだ，頭上 位への変换にてる眼振の発現はなかつたが，頭上位より 復帰させた時には，振幅の小ざ上向性垂直性眼振が 䄪 1 秒の潜伏期を沶いて 3 ４ 回発現した。尾上位への 变換では，同様汇䄪 I 秒の潜伏期の後振幅の小さい上向 性垂直性眼振か゚ 3〜4 回発現し, 尾上位上りの復帰位に 颃いては，比較的大きな上向性垂直性眼振が約 1 秒の潜 伏期を和いて 3〜4 回発現した。

4. 組織学的所見 (図 13)

損傷部位は，舌下神経核上部の高さに相当して，前庭 神経下行路核の下部の背外側部に少しの損倁があつた。

No. 24 , क $2.2 \mathrm{~kg}$

1. 刺激奏駼

刺激電检を、㨉入した丈で，術側向水平幽腿振が観察さ
れた。刺激時の眼振は，術側斜上方に向ら斜性眼振が発 現した。

\section{2. 電気凝固実験}

電気凝固時は，両眼共術側向水平性眼振が観察され た。

\section{3. 電気凝固後の観察}

電気凝固後は，上向性垂直性自発眼振が観察された。 頭位变換に上る眼振の観察を行つたが，術側下位への 変換では自発眼振が消失し, 術側下位からの復㷌の場合 には術側上向性の斜性眼振が発現した，健側下位への変 換及び復帰に打いては術側向水平性眼振が観察された。

頭上位及びその復帰位に 扎いては自発眼振に変化な 々，尾上位及びその復帰位では自発腿振が消失した，

4. 組織学的観察 (図 14)

損傷部位は，外転神䌊核の高さに相当して，前庭神释 外側核の背内側部を大さ損傷し，内側核の外側部にを 損傷が及えでいた。

\section{略語説明}

$\mathrm{Cl}$ : nuleus cuneatus lateralis

Cod: nucleus cochlearis dorsalis

$\mathrm{Fl}$ : fasciculus longitudinalis

Gcp : griseum centralis pontis

$\mathrm{Gp}$ : griseum pontis

Ic : nucleus locus loeruleus

$\mathrm{Oi}$ : nucleus orivalis inferior

Os: nucleus olivaris superior

PmV: nucleus paramedium reticularis

$V-i$ : nucleus trctus spinalis trigemini inferpolaris

$V$-me: nuclens nervi trigemini mesencephalicus

$V$-mo: nucleus nervi trigemini motorius

$V-o$ : nucleus tractus spinalis trigemini oralis

$V-p v$ : nucleus nervi trigemini sensibilis principulis subnucleus ventralis

VI: nucleus nervi, abducentis

VII: nucleus nervi facialis

VII-1: nucleus vestibularis lateralis

VII- $m$ : nucleus vestibularis medialis

VII-sp: nucleus vestibularis spinalis

VII-s: nucleus vestibularis superior

$X:$ nucleus nervi vagi dorsalis motorius

$X I I$ : nucleus nervi hypoglossi 
图 1 No. 2

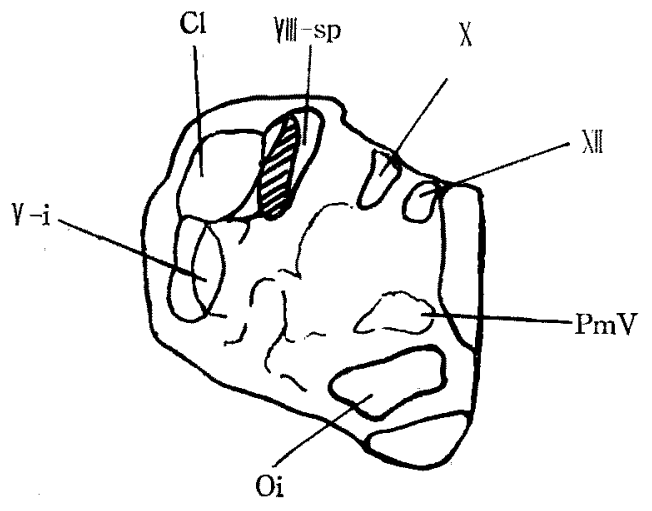

图 2 No. 3

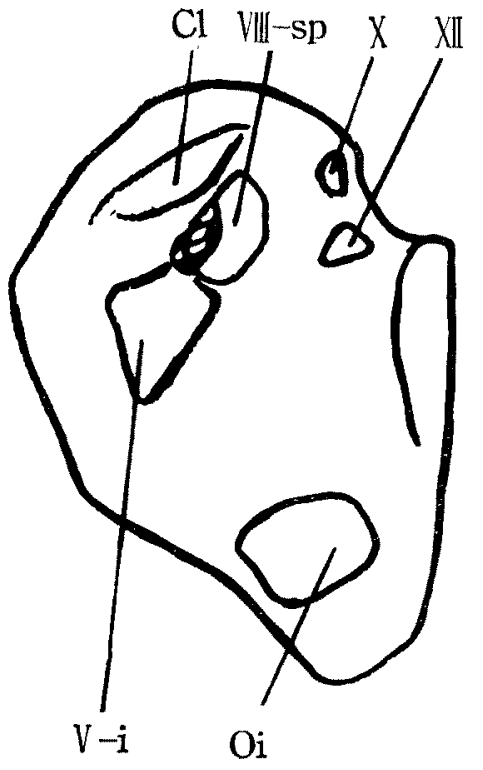

図 3 No. 4

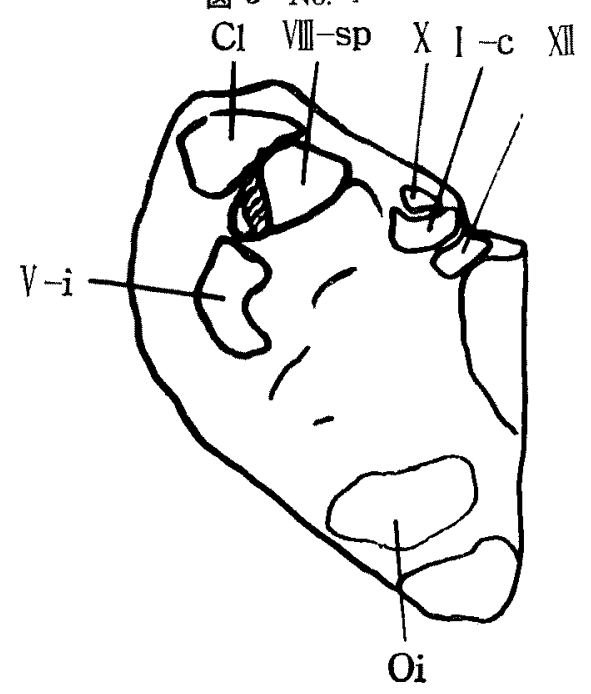

图 4 No. 5

VIII-sp VIII-m

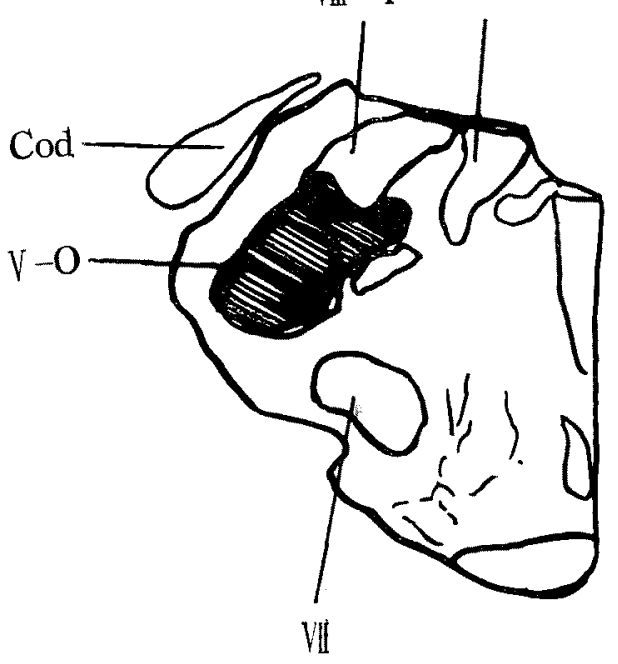

图 5 No. 6

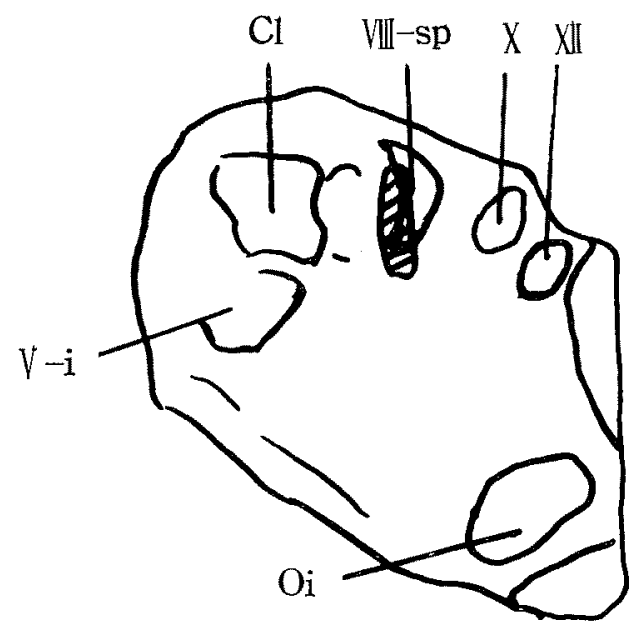

图 6 No. 7

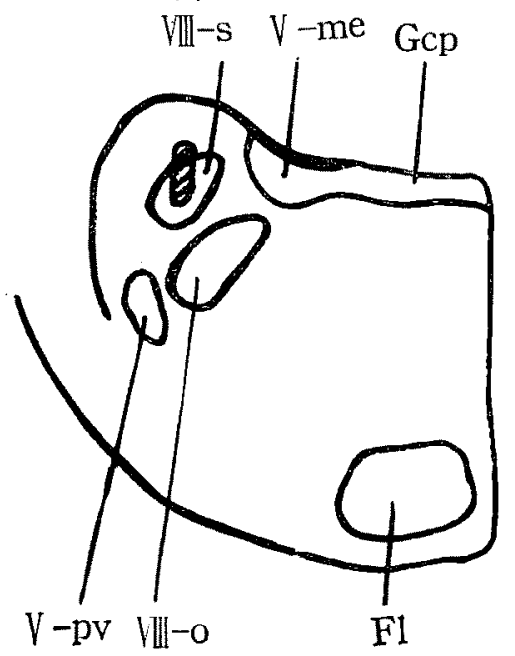


图 7 No. 8

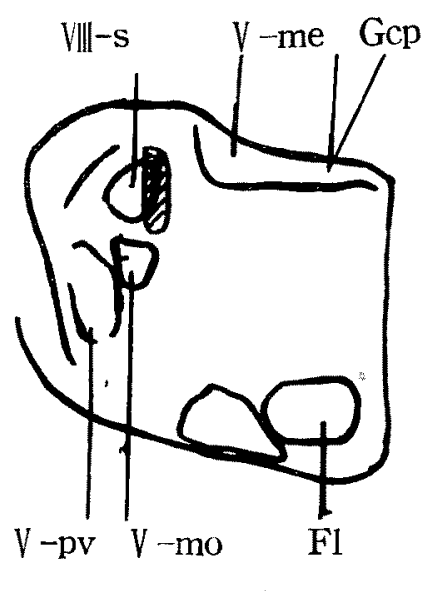

图 8 No. 9

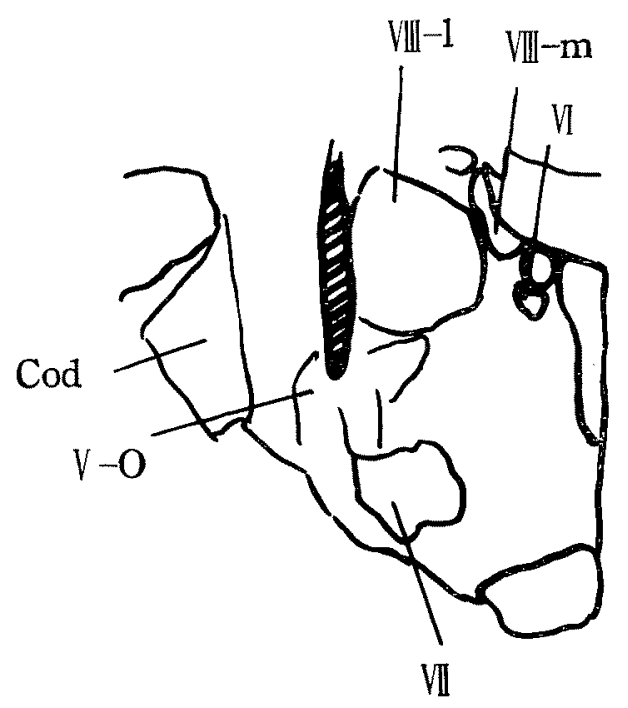

图 9 No. 11

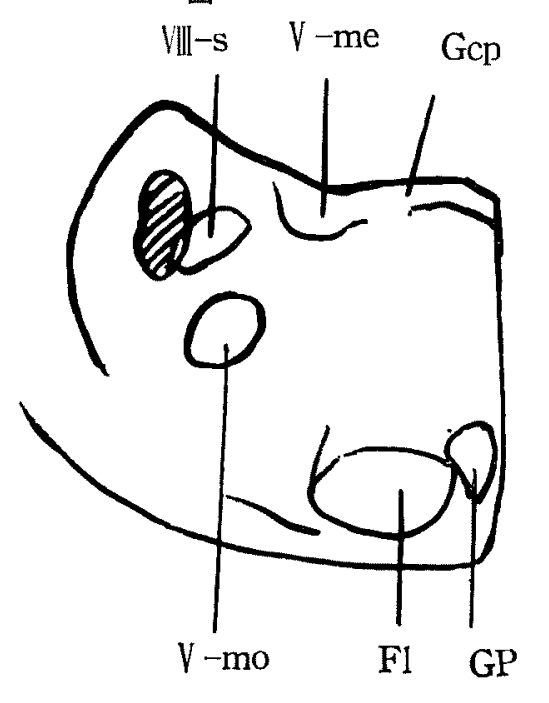

图 10 No. 13

VIII-sp VIII-m

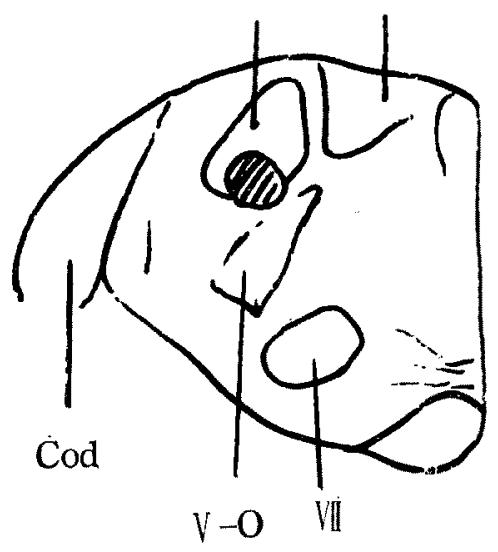

图 11 No. 15

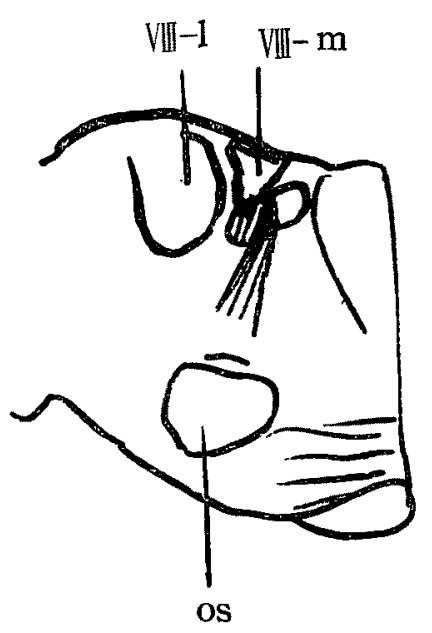

図 12 No. 19

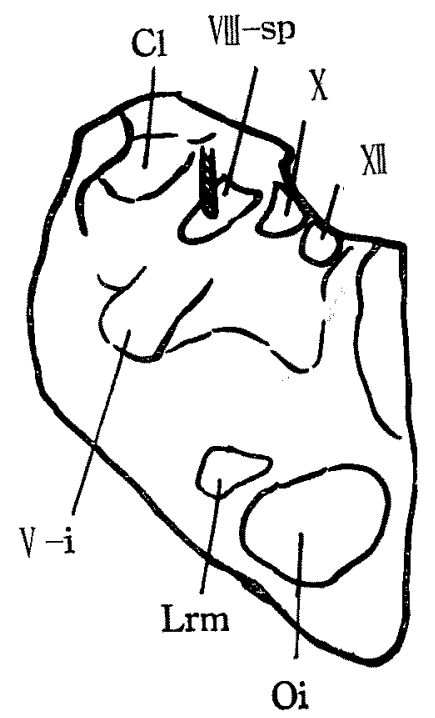


图 13 No.20

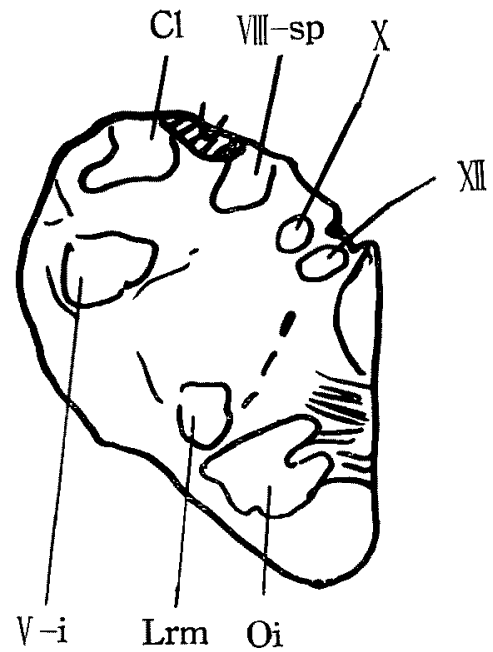

图 14 No. 24

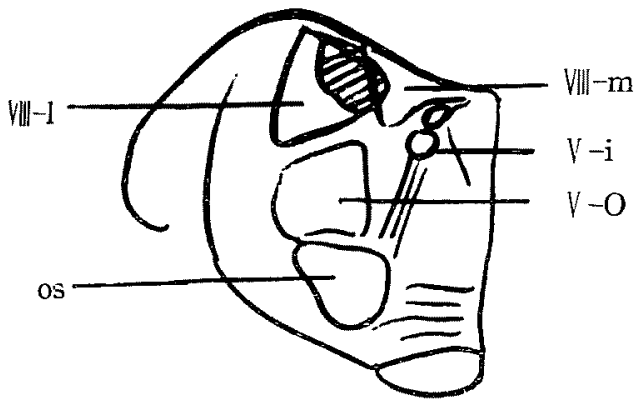

図 15 No. 26

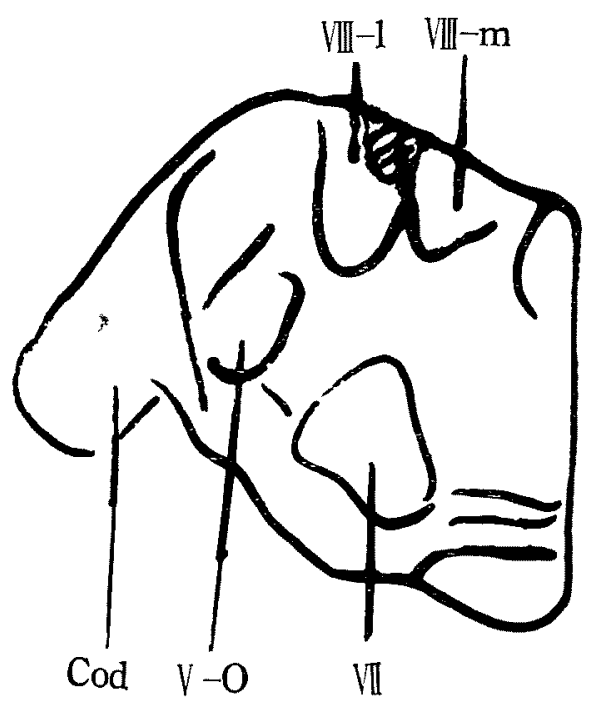

図 16 No. 28

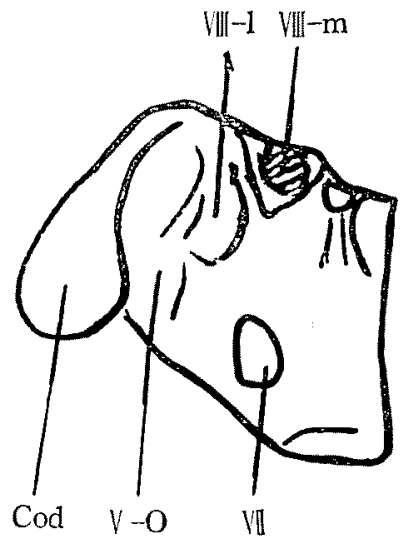

No. 26 क $2.8 \mathrm{~kg}$

1. 刺激㐓鱁

刺激時の眼振は，術側向水平性腿振であつた。

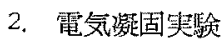

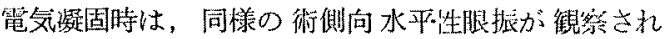
た。

\section{3. 笔気凝固後の観察}

電気凝固啳は，術側向水平性腿振が発現した。

頭位変換眼振は，術側下位への変換の際には，自発腿 振の振偪がささくなり遂に眼振が消失した，術側下位よ りの復㴆の際には自発眼振に变化はみられなからた。䛧 侧下位への変換では，自発眼振の振幅が增強され，元の

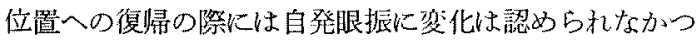
た。頚上位，尾上位，てれぞれの復㷌の際は，自発服振 に変化は譛めら玌なかつた。

4. 組䅧学的観繁 (図 15)

損傷部位は，顏面神経核の窝さに相当して，折庭神释 外側核の背内側部及び内側核背外側部の一部であった。

No. $28, \quad 32.7 \mathrm{~kg}$

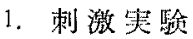

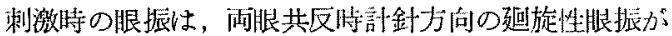
観察されたが，眼唗の大きさは術側に比し䛧侧のうが人 きかつた。

2. 電気凝固䒠蛪

電気论凝固時は，同様に健側の眼振の力が大きい反時㖕 針力向の建旋性眼振が発現した。

3. 電気凝固後の観察

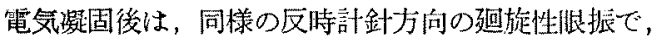


図 17 制激時恨振, 凝固後眼振, 㖽位変换眼振, 組織学的所見の関係

\begin{tabular}{|c|c|c|c|c|c|c|c|c|c|c|c|c|c|c|}
\hline \multirow{3}{*}{$\begin{array}{l}\text { 猫 } \\
\text { 番 } \\
\text { 号 }\end{array}$} & \multirow{3}{*}{$\begin{array}{l}\text { 制 激 時 } \\
\text { 䐚振 }\end{array}$} & \multirow{3}{*}{$\begin{array}{l}\text { 凝 固 後 } \\
\text { 自発限振 }\end{array}$} & & 頭 & 位 & 変 & 換 & 眼 & 振 & & \multicolumn{4}{|c|}{ 粗織学的所見 } \\
\hline & & & \multicolumn{2}{|c|}{ 溒側下位 } & \multicolumn{2}{|c|}{ 健侧下位 } & \multicolumn{2}{|c|}{ 頟上位 } & \multicolumn{2}{|c|}{ 尾上 位 } & \multirow{2}{*}{ 背側核 } & \multirow{2}{*}{ 内倪核 } & \multirow{2}{*}{ 外側核 } & \multirow{2}{*}{\begin{tabular}{|l} 
下行路 \\
核
\end{tabular}} \\
\hline & & & 变換 & 復㷌 & 变換 & 復慢 & 变換 & 復惯 & 変換 & 復州 & & & & \\
\hline 5 & 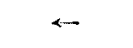 & $\leftrightarrow$ & 增強 & $\leftrightarrow$ & 抑制 & $\leftrightarrow$ & $\leftarrow$ & $\leftarrow$ & $\leftarrow$ & 4 & & & & + \\
\hline 19 & $\leftrightarrow$ & $(-)$ & $\leftarrow$ & $(-)$ & $\rightarrow$ & $(-)$ & $(-)$ & $(-)$ & $(-)$ & $(-)$ & & & & $t$ \\
\hline 20 & $\hat{\imath}$ & $(-)$ & $(-)$ & $(-)$ & $(-)$ & $(-)$ & $(-)$ & $\uparrow$ & $\uparrow$ & $\uparrow$ & & & & + \\
\hline 24 & $\nearrow$ & $\hat{\imath}$ & 㧕制 & $\nearrow$ & $\rightarrow$ & $\because r$ & $\hat{\imath}$ & $\uparrow$ & 抑制 & 㧕制 & & + & + & \\
\hline 26 & $\rightarrow$ & $\rightarrow$ & 㧕制 & $\cdots$ & 增強 & $\rightarrow$ & $\rightarrow$ & $\rightarrow$ & $\rightarrow$ & $\rightarrow$ & & + & + & \\
\hline 28 & $\curvearrowleft$ & $n$ & $\cdots$ & $\curvearrowleft$ & $\uparrow$ & $n$ & $\rightarrow$ & $\curvearrowleft$ & $\leftrightarrow$ & $\curvearrowleft$ & & + & & \\
\hline
\end{tabular}

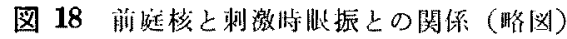

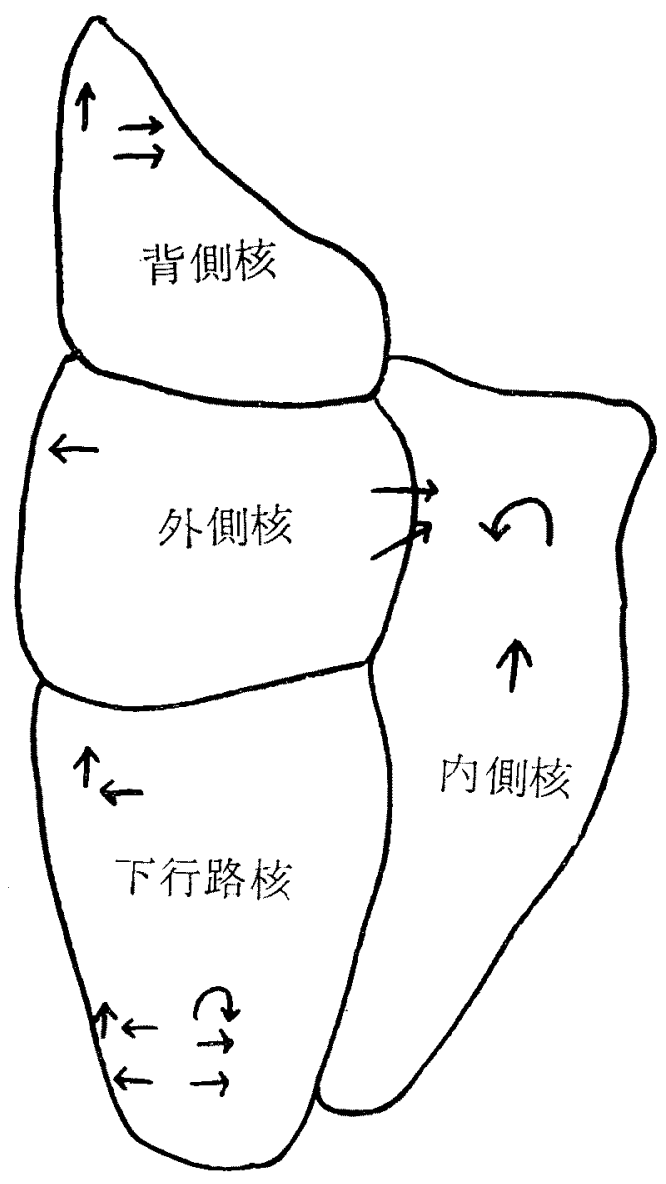

梿側の万が術㒋に比し大きさの大きい自発腿振が発現し た.

熋気凝固後 20 分に頭位变換眼振を観察した，術侧下 位への变換で性 健側向水平性眼振が $2 \sim 3$ 回発現し，そ の後はもとの自発眼振となり, 元の体位に復帰した時に は自発眼振に变化はなかつた。健側下位に变換すると上 向性垂直性眼振が 2 3 回認められ，その後は上述の䢙 旋性眼振となつた，頭上位への变換では術側向水平性眼 振が 2 3 回, 尾上位への変換では 健側向水平性眼振肪

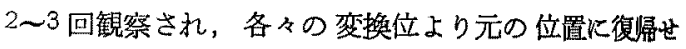
しめた時には自発眼振に变化なからた。

4. 組織学的锶察 (図 16)

損傷部位は，顏面神経膝状部の高さに相当し，前庭神 経内側核を大きく損傷している。

以上の症例の5ち代表的な6例を図17で示す。

各前庭核で刺激時に 発現した眼振の略図を図18亿示 与.

\section{IV. 考按並びに総括}

前庭核と眼球振盟との関係を追求すべく古くから数多 くの実験がなされているが未だ定説というむのが無い状 態である. Leidler $(1913,1916)$ は，家鬼の外側核から 出る弓状線維の損傷で術側向水平性眼振, 又損傷がそ祅 上り上部だと健側向水平性眼振, 下行路核の損傷では䢙 旋性眼振を主と乙た混合性眼振を観察し, Spiegel, Sato （1927）は，犬の前庭核領域殊飞外側核の上部及ひ背㑬 核を損傷して，下问性垂㨁性眼振，健側向水平性眼振を 観察した，高橋 (1931) は，家束の背側核の損稘より水 平性眼振，内側核及び外側核の損傷より水平性腿振を主 とした混合性眼振の発現を発表し，松下 (1938) は，家 束の外側核及び内側核の損傷で下向性垂直性腿振，背僛 
核及び外側核附近の損傷により垂直性及び斜性眼振が発 現することを報告している．大和田（1949）は，猫の前 庭核の損侮実験を行い，垂直性眼振は背側核に起因し， 迴旋性眼振は内側核領域借関係があると述べている。 Cranmer (1951) は，外側核と内側核の電気刺激で術側 向水平性眼振，同部を大きく電気㠜固により損傷寸ると 健側向水平性眼振が発現するのを観察し，眼振の方向は 両側の前庭核間の不均衡により起り，その不均衡の原因 は刺激の強さのみでなく，破液の程度，麻酔の深さ，疲 労現象（刺激を反復すると眼振方向が 逆転する場合す り）によると説明した，又，背側核の損傷で 垂直性眼 振，背側核と外側核との境界部の損傷で斜性眼振，小脳 特淿部の破壊で術側向水平性眼振を認めている。阿部 （1960）は，家鬼の前庭核破罗案験を行い，水平性眼振

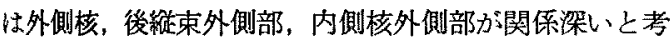
兑，後維束の交叉性線維を重要視している. 又垂直性眼 振恃背側核領域を含む I.A.K. (Innere Abteilung des Kleinhirnstiels）附近の損傷により発現すると述べてい る. Carpenter 等 (1960) は，猫の下行路核の破壞で趈 轱性眼振を主とした混合性眼振，下行路核及び外側核の 破壤でる同㥞に趈旋性眼振を主とした混合性眼振を観察 している.

他にも Marbung (1912), Crosby (1953), Bergmann 等 (1960)，Montandon (1964) 等々数多くの研究がな されている.が，上述の如く各々の前庭核と眼振発現に ついて画一性がない，前庭核と眼振発現につき現在迄の 報告をまとめると図 19 となる。

次に前庭神経の主絟路について考察してみる，後縱束 の主成分が前庭神経の二次線維であり，大部分交叉して 反対側の後縦束に入り，動眼，滑車等の動眼神経核に終 るといらのが定説となつているが異論をとなえる人るい る(四 20)。

图 19 各前庭核と発現した眼振との関倸 (文献的縤計)

\begin{tabular}{|c|c|c|c|c|c|}
\hline & 水㭋性 & 金直性 & 迴掟性 & 斜 & 性 \\
\hline 北 側 核 & 2 & 3 & 0 & & 2 \\
\hline 内 例 核 & 1 & 2 & 1 & & 1 \\
\hline 外 侧 核 & 5 & 4 & 1 & & 3 \\
\hline 下行路 核 & 0 & 0 & 2 & & 0 \\
\hline 背侧核・外倒核 & 0 & 1 & 0 & & 1 \\
\hline 内倒核 - 外揑核 & 1 & 1 & 0 & & 0 \\
\hline 背側核・内侧核 & 1 & 0 & 0 & & 0 \\
\hline
\end{tabular}

图 20 前庭神䋊の主径路（小川教授による）

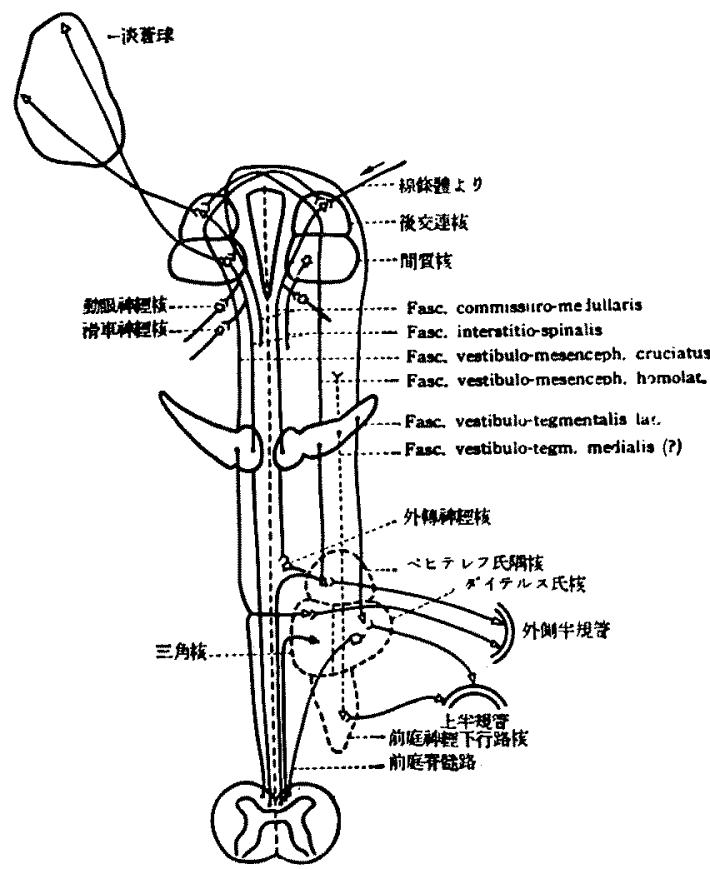

图 21 前庭神経核とその中心経路を示す略图 (小川教授による)

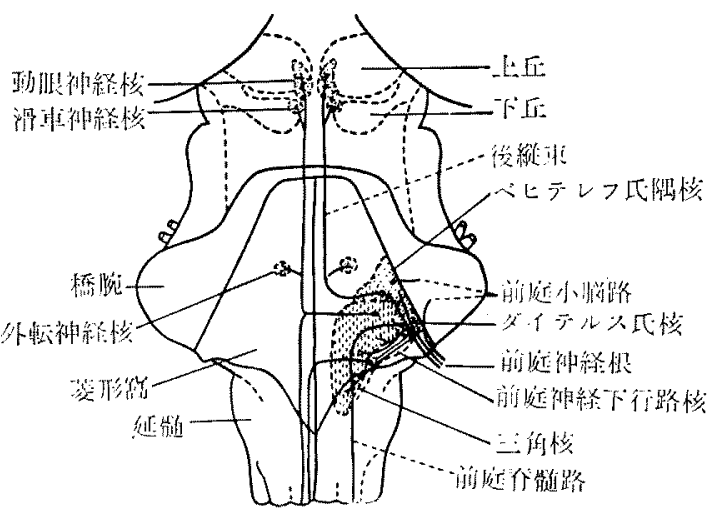

従来，上行性線稚の起始核として前庭神経下行路核を 除く他の能庭核が考えられていたが，最近では外側核 よりの上行性線維を否定する考无方が強くなつてきた (Gray, 1926; Rasmussen, 1932; 小川1, 1951; Montandon, 1964)，近年の米国での説を図 21 に示す．又下行 路核からは下行性の線維のみが出るといら説が多いが， 小川 (1951), Carpenter (1960) 等怡強否定し, 上行 件の線維の存在を確信している。 
前庭核の終止核として小脳の室頂核も言われ，又前庭 神経諧核から小脸へ，小脳から外側核に入る線維が沢山 存在する。

動眼，滑車，外枟神経等眼球運動支配の諸筋は前庭系 之密接な関保にあり眼振発現の重要な反射路となつてい るが，動眼機搆本来の目的のために高次中枢からの支配 を受讨ている. Muskens (1934) は線状体，淡荅球を 高位の前庭中枢と考克, Spiegel 等 (1941), Cranmer (1951) 等は小脳に，Cawthorne (1942) 等は側頭葉を 高位中枢と考光ている。一般に高位中枢は前庭系に抑制 的に㗢くと考学られている.

他方, Lorente de Nó $(1931,1933,1935)$ は, 前庭

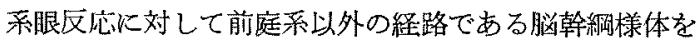
通る経路があるといら考察を導入した. Magoun (1950) は中㨫網样体を刺激し，この部が生体の賦活系として作 用する事を証明した。.Montandon（1964）は，中䋞眼 振野を電気刺激し，1 側の中脳眼振野の刺激は，刺激側 前庭眼振野の反応を抑制し非刺激側前庭眼振野の反応を 增強すると述べている，以上の如く眼振発現炕関して は，前庭系への色々な因子が介在する。

1. 水平性眼振について

刺激眭水平性眼振を発現したものは，No. 3, No. 4, No. 5 , No.6, No. 7 , No. 8 , No.9, No.19, No. 26 99 例である。

水平性眼振に関しては Marburg (1912) が外側核の 腹方下部の損傷で眼振登現を認め，Leidler (1913)は, 顔面神絟等状部の高さに相当して外側核を損傷すると術 側向水平性眼振が生し，損賃部位がそれより上部だと健 側向水平性眼振が生じると述べている，小川 (1951) は，一側の後縱束が怔眼神経核と前庭神経核の間の高さ でこわされると術側问水平洗眼振，前庭神経の末梢部の 破猡で健側向水平性腿振が起り，二次線維は大部分交叉 性であると述べている. Spiegel, Sato (1927) は，犬の 前庭神経核領域特に外側核及び留側核の領域を損傷し， 下向性画直性眼振及び健側向水可性眼振の発䍐を報告し ている，高橋 (1931) は，背側校が水平性眼振に関与し， 又外側核及び闪側核の一部の損傷で水平性眼振を主とし た混合性眼振を家乘にて認めている. Cranmer (1951) は，猿を用いて军睮を行い，外倒核電気刺激により術側 向水平性眼振，同部の電気凝固に上り健側向水平性眼振 となり，眼振方向が这転するのを認めた。㕛内側核の刺 潵でも健側向水平性眼振を認めている。阿部 (1960)

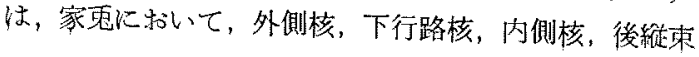

外側部等の破壞により水平性眼振の発現を認めたが，そ の損偟の程度から水平性腿振の発現には外側核及び後继 束外側部が最も関係ある部と推定した．そして後維束の 交攴性線維が 重要な役割を演していると述べている。 Montandon (1964) は，背側核之内側核の一部の電気 刺激で術側向水平泩眼振を, 電気凝固で水平性眼振を主 体とし，垂值性眼振を合九た混合性眼振を認め，刺激と 凝固で眼振方向は変化しないと述べている．眼振方向の 不変という点で Cranmer (1951) の説と対立している.

水平性眼振は文献の上では外側核に由来する旨の報告 が多い。

私の実験では，下行路核下部の刺湤により水雨性眼振 の発現したのが, No. 3, No. 4, Ne.6, No.19, 下行路 核上部では No. 5, である. No. 9 は外側核の外側部之 三叉神経脊顝路核の一部に損傷があり，外側核外側部の 刺激化上り水平性眼振が発現したと思われる。 No. 26, は外側核の内側部及び内側核の外側部の一部に損傷があ る. No.7, No. 8, は背側核の最上部の刺激炕より水平 性眼振が発現している。このように各々の前庭神経核加

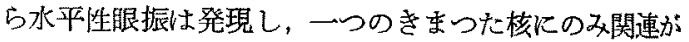
あるとは言觉ない

眼振の方向について, No.6, No.7, No.8, No.26 生 術側向, No. 4, No. 5, No.9, No.19 は健側向である. 小川に上ると術側向は核及び二次線維，健側向は末梢の 損傷より起るが，私の实験ではこの区別はつけ難い， Leidler は提傷部位の高さを問題としているが，No.9 と No. 26 は大体同じ高さでも眼振方向は逆であり， No. 3, No. 4, No. 6, No. 19 は下行路核の最下部の高さ でも両方向への眼振が発現しているので，彼の仮説のみ では説明されない。

左右の眼振の大ささの異同について現在まで交献的記 載はないように思われる。私の実験では, No.6, No.19, No. 28 (反時計針方向迴旋性眼振例) の 3 例飞执いて， 健䚋眼が衍側眼上り眼振の振幅が大きい事が䍊察され た. 何に起因寸るか速断は禁物だが，二次線維の配分の

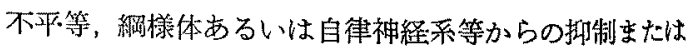
促進的影響等が考㝋られる。が，たた祱に事実を述べる 丈に止めて扰く

2. 垂直性眼振について

刺激の際に垂淔性眼振が 認められたものは No. 11, No. 13, No. 15, No. 20 の 4 例である。

Marburg (1912) は，外側校䧗尾部の椇傷で水平性眼 振を観察し，外転神経核の高さに打ける損傷により垂直 
性眼振が 発現すると述べ，松下（1938）は，外側核及 び内側核の損傷で下行性垂直性眼振を観察し，大和田 （1948）は，垂直性眼振は背側核領域が関係し，その小 脳側と延歌側とでは損稘による眼振の方向が逆である と述べ，垂直性眼振の上下 2 万向の由来について子背 側核の支配によると推論した。大谷等 (1951) は家象 の I.A.K. 附近の破壇により垂直性眼振を諗め，小川 (1951) は家鬼では特に 垂直性眼振が 発現しやすい, ペている. Cranmer (1951) は，猿の背側核を電気凝固 し垂直性眼振を認め，Crosby (1953) は外側核及び背側 核の上部の刺激で 垂直性又は 斜性眼振を観察し，阿部 （1960）は垂直性眼振の解発部位は背側核を含む I.A.K. 口部, 聴神経侵入部上り前庭神絰侵入部に至る内側核で あると述べている．文献的考察では前庭神経核の上部， 即ち背側核及び外側核と内側核の上部にその起因を認め るものが多い。

私の実験では 垂直性眼振はいずれも上向性 だつた。 No. 11, No.13, No. 15 は顔面神経核より上部の高さに 相当して核の損傷があり，一般には，4つの前庭核を 1 つと考光た場合その上部の刺激によつて垂直性眼振が発 現する傾向があると言える。しかし他方には同様の部分 に損傷の認められた No.7，No.8，No.9，No.26 等は垂 直性以外の眼振が発現し，又 No. 20 は下行路核の尾部 即ち舌下神経核上部の高さで垂直性眼振が認められたの で，必ずしも部位的関係によるものとは断定されない 水平性眼振の場合々同様，各々の前庭核のうち特異な 核からのみ垂直性眼振が発現するといち現象は認められ なからた。

\section{3. 迴旋性眼振について}

画旋性眼振を示したものは，No. 2, No.28の2 例で ある。

Leidler (1916) は家鬼に扎いて下行路核損傷により迴 旋性眼振を主とした混合性の眼振を認め，高橋（1931） は家鬼の外側核及び内側核の損傷より，水平性眼振を主 とし迴旋性腿振を含む混合性眼振を，又内側核及び背側 核の損傷上り宦旋性眼振を観察した。大和田 (1948) は 廻旋性眼振怯内側核領域力：関倸し，非術側へ向う眼振を 発現すると述べている．阿部（1960）は外側核及び内側

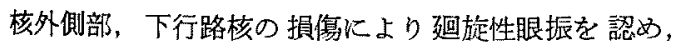
Carpenter 等 (1960) は猫の下行路核, 下行路核及び外 側核の破壊上り廻旋性眼振を認めている。

私の实験では No. 2 は下行路核の下部の刺激より時 計針方向廻旋性腿振，No. 28 は内側核の刺激により反
時計針方向廻旋性眼振が発現した。

4. 斜性眼振について

No. 24 は, 刺激時, 電気凝固時，電気凝固後の自発 眼振が異つた。

電極を拽入したのみで術側向水平性眼振が発現し，刺 激によつてその水平性眼振が上方に引張られたかの如く 術側上向性斜性眼振が登現し，電気凝固の際は術側向水 平性眼振，更に電気㠜固後は上向性垂直性となつた．組 織学的検少の結果，外側核に大きく又内側核の外側部に も少しく損傷が認められた，これを推測するに，電極を 插入したごく小さな部は水平性眼振を発現する分野であ り，刺激に上りその影響が周囲の垂直性眼振を呈する分 野に及んで水平性眼振十垂直性眼振となり，丁度ベクト ル上らの関保で斜性眼振が発現した。電気凝固時には水 平性眼振の誘発が強調され，電気㠜固後は水平性眼振を 呈する分野からの影響が脱落してその結果垂直性眼振が 発現したと考兄られる。

斜性眼振についての文献的記述は少い，松下 (1938) が家束の背側核及び外側核附近の損傷で斜性眼振の発現 を報告し，Cranmer (1951) は背側核と外側核の境界 部，Crosby（1953）は背側核及び外側核の損傷で斜性 眼振を観察し，阿部 (1960) は外側核及び内側核外側部 を斜性眼振の解発部位と考えている。

私の実験でもCranmer の如く2つの核にまたがつた 部より発現している. 水平性眼振及び垂直性眼振の発現 に関する責任分野を組織学的所見に基づいて，水平性眼 振は外側核に，垂直性眼振は内側核によると推論するこ とも出来るが，他方内側核を刺激した No. 15 では垂直 性眼振, No. 28 では廻旋性眼振が観察され，外側核と 内側核の両核を刺激した No. 26 では水平性眼振が発現 している。

以上，前庭核刺激により発現した眼振の 関係を四 22 に示す

最後に，前庭核と眼振との関係に掂いて， muskens

図 22 前庭核刺激之眼振との関係

\begin{tabular}{|c|c|c|c|c|c|c|c|}
\hline & & & 水平性 & 垔直性 & 超旋珄 & 斜 & 性 \\
\hline 背 & 側 & 核 & 2 & 1 & & & \\
\hline 内 & 側 & 核 & & 1 & 1 & & \\
\hline 外 & 側 & 核 & 1 & & & & \\
\hline 下 & 预 & & 5 & 2 & 1 & & \\
\hline 内側 & 亥・办 & 核 & 1 & & & & 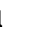 \\
\hline
\end{tabular}


（1934）の完全に分業が行なわれているとした説，Cranmer (1951) の外側核内側核 ら垂直性眼振，背側核之外側核の境界部から斜性眼振が 発現するという上らな，絶対的な分業説は賛成しか放 る. 私の実験成績及び先人の実賖的統計から考察する と，それ它れの核からいずれる各種の眼振澄現してい る。例えば，内側核が水平性眼振の及に関保するのでな

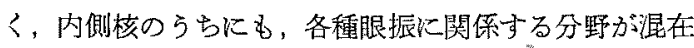
する，即ち各々の前庭核が種々の眼振を発現する分野を 持ら，午の分野は各前庭核の内に混在するむのと考古 る。更に，小脳の核，他の高位中枢，絟様体等が腿振発 現に関連して複雑な様相を呈するに違いない。

一般には，下行路核からの上行性線維の存在を否定す る考光万が強いが，私は小川 (1951), Carpenter (1960) の述べるように，上行性線維の存在を確信する.何故な らば，下行路核の刺激により，種々の眼振が発現しここ れは上行性線維なしには考えられない

5. 電気刺激時眼振上電気凝固後自発腿振について 刺激時之凝固後の眼振方向について，Cranmer(1951) は，右外側核を電気刺激し右方向水平泩眼振の発現を認 め, 電気㠜固後は左方向水平性眼振となり，眼振方向の 逆転を報告し，それを雨側の前庭核間の平衡の不均衡に より説明している，Montandon (1964) 《，前庭核の 刺激及び㠜固について眼振方向の变化はなく，力向は一 定であると述へ，高位中枢（間脎腿振野）の影響を強く 考元ている。

私の実験では, No. 5, No.6, No. 26, No. 28 では刺 激時と㠜固後とで眼振方向に变化なく, No. 2, No. 4, No.9, No.19, No. 20 では刺激時に眼振著明なるにも拘 らず焼灼後眼振は発現しない. Cranmer (1951) の言ら 加く, 刺激の強弱, 破壊の程度, 麻醉の深さ, 疲労現象 等の影響も考之られる，No. 24 では，電極插入時は水

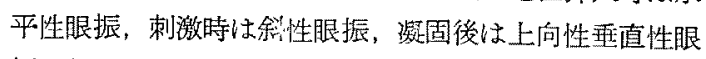
振が認められた。

両前庭核問の平衡失調のみで説明されるなら刺激時及 び烧灼後眼振とでは眼振方向の変化がみられなければな らない、しかしながら夷跲成績の示す如く必ずしも眼振 方向の变化が友られないのは単に両側の前庭核間の均 衡の不一致の众で眼振方向が決定されるのではなく， 他の要素の影怊をも考学さるを得ない。これに関し， Lerente de Nó (1931，1933，1935) は縌様体少眼振機 構に重要な役割を果すと述べ, Montandon (1964) は, 前庭核が眼振機棈の全部を代表するものでなく，すべて
の動眼神絽核と前庭核との複合体によつて機能が達成 し，中脳眼振野がこの系に促進又は抑制的に関与すると 考觉ている.

6. 頭位変換眼振について

猫を台に固定したまま，術側下位，健側下位，頭上 位, 尾上位，それぞれの体位を元の位直にもどす復帰位 の8 万向に 90 度頭位を変挻せしめ, 眼振の観察を行つ た。

観察は, No. 5, No. 19, No. 20, No. 24, No. 26, No. 28 の 例について行つた (図 17 参照).

健, 術側への䡃換について：No. 5 は術側下位にて 自発眼振の振幅が大きくなり，健側下位への変换で怯振 幅が小さくなる. No. 19 は, 術側への変換で水平性眼 振が誘発され，健側下位では眼振方向が逆転し，No. 24 は, 術側下位で自発眼振が消失し，その復門位では斜性 眼振が誘発され，健側下位では垂直性自発眼振が淮側向 水平性眼振となる．No. 26 では，術側下位への变換で 眼振の振幅が小さくなり，健側下位では逆浱幅が大き くなる。

No. 28 は術側下位で趈旋性自発眼振が 健側向水平性 眼振となり，健側下位で上向性垂直性眼振となる。

頭上位, 尾上位への変換：No. 20 で頭上位よりの復 帰位にて上向性垂直性眼振が誘発され，尾上位では変換 時復班時に同様の上向性垂直性腿振が発現するが復婦の 際の眼振の振幅の方が大きい，No. 24 では，尾上位及 びその復帰位で自発眼振が抑琍される。 No. 28 は, 頭 上位で術側向水平性眼振，尾上位で健側向水平性眼振が 誘発される。

以上の誘発された眼振は，すべて誘発されるまでの潜 伏期は 1 2 秒, 眼振誘発の持続時間は 2 5 秒, 眼振数 は3〜10回である.

Cohen 等 (1964) 瑐半規管又は後半規管からの神 経の電気刺激で垂直性眼振を，外側半規管からの神経の 刺激で水平性眼振を，また 1 側の前半規管及び後半规管 からの神絽の同時刺激で廹旋性眼振の発現を観察した。 私の 实碒成續では，電気刺激時又は電気凝固後の眼振 が水平性眼振の場合は健術側方向へ変換で, 垂直性腿 振の場合㥧上位尾上位万向への変换で，眼振の性状か; 特に変化する傾向がある，この事拣は，健術側方向への 頭位変撸では主として外側半規管が, 頭上位尾上位方向 への变換では主として前及び後半規管が刺激され，頭位 変換による刺激の影響と前庭核の障害部位との関伱加 ら，各種の眼振が発現する之推論される，廻旅性眼振が 
発現した No. 28 において頭位変換により各種眼振の発 現した事実は，電気凝固に上る障害之頭位变換に上る影 響方腹雑なためと考兵る。

又, 刺激時又は凝固後眼振の急速相方向への頭位变換 で眼振が抑制されて振幅が小さくなり，湲徐相方向への 変換で眼振が增強され 振幅が大となる傾向が琶められ た.

\section{V. 結語}

1. 前庭核の各部を電気刺激した際各種眼振が発現す ることを認めた，その際刺激部位を電気凝固した後, 組 蟣学的に検査して刺激部位を判定し, これと眼振の性状 との関係を考察した.

下行路核，外側核，内側核，背側核の夫々について， いずれも水平性㕛は垂直性眼振の発現を認如，内側核， 下行路核の刺激上り延旋性眼振，外側核及び内側核の一 部の刺激より斜性及び我平生眼振を認めた，

以上の事より，前庭核と眼振との関係汇ついて，各前 梃核の内に各種眼振に関係する分野が湿在する事を推諭 した.

2. 刺激部位を、 30 ボルト 30 秒直流通電で電気㠜固 させ，その後自発腿振を観察した。刺激時と凝固後とで 腿振に 变化のないるのが 4 例, 凝固後 自発眼振が 発現 しないものが 5 例, 腿振に变化のあつたもの1例を癹め t.

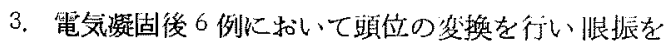
観察した，電気凝固後 自発眼振の発現した 4 例に括い て, 自発眼振が 水平性のもの 2 例では健, 術側位力问 の变換で，垂直性及び迴旋性のもの各 1 例では煡, 術側 -頭上位, 尾上位方向への变換で眼振の性状が 変化し た．電気凝固後自発眼振のない2例については，刺激時 の眼振が水平性のもの健, 術側方向への変換で, 垂直 性のものでは頭上位・尾上位方向の变換で眼振の性状が 変化した。この䟢発現する頭位変換眼振は，潜伏期が 1 〜2 秒，持続時間が数秒の一過性のものである事を知つ た。

\section{參考文献}

1) 阿部稪一：前庭核破流飞上る眼振の钼察，日耳 , 63; 434,1960, 2) Buchman, A.R.: The course of the secondary vestibular fibers in the cat. Journ. Comp. neurol, 67, 183, 1937. 3) Bergmann, F; Lachmann, J.; Monnier, M: Central nystagmus and its relation to the mechanism of vestibular Nystagmus. Confin. neurol, 20, 214, 1960.
Bergmann, F.; Lachmann, J.; Monnier, M; Kriepp, $P$ : Central nystagmus III. Functional correlation of mesodiencephalic nystagmogenic center. Am. J. physiol. 197, 328, 1958. 5) Crosby, E.C.; Nystagmus as sign of central nervous system involvement. Ann. Oto-Rhino-Laryng. 62, 1117, 1953. 6) Carpenter, M.B.; Alling, F.A.; Bard, D.S: Lesions of the descending vestibular nucleus in the Cat. Journ. Comp. Neurol, 114, 39, 1960. Cawthorne, T.E.; Fitzgerald, G; Hallpike, C.S.: Studies in human vestibular function. a) Observation onthe directional preponderance "Nystagmusbereitschaft" of caloric nystagmus resulting from cerebral lesiom. Brain 65, 115, 1942. 8) Cawthon, T.E.; Fitzgerald, G.; Hallpike, C.S.; Studies in humam vestibular function. b) Observation on the directional preponderance of caloric nystagmus "Nystagmusbereitschaft" resulting from unilateral labyrinthectomie. Brain, 65, 138 1942. 9) Crenmer, $R$ : Nystagmus related to lesions of the central vestibular apparatus and the cerebellum. Ann Oto-Rhino-Laryng. 60, 136, 1951. 10) Cohen, B.; Suzuki, J.; Bender, M.B.: Eye Movements from semicircular canal nerve stimulation in the cat. Ann. Oto-Rhino-Laryng. 73, 153, 1964. 11) Dusser de Barenne: Über vestibular Augenreflex V. Vestibuläre Untersuchungen nach Ausschaltung einer Grosshirnhemisphäre Untersuchungen nach Ausschaltung einer Grosshirnhemisphäre beim Kaninchen. Graefe's Arch, f. Ophthal. 111, 374, 1923. 12) Gernrndt, B.E., Thulin, C.A.. Vestibular connections of the brainstem Am. J. physiol, 171, 121, 1952. 13) Gray, L.P.: Some experimental evidence on the connection of the vestibular mechanism in the cat. Journ. Comp neurol.41, 319, 1929. 14) Ingvar, S.: Zur Phylo-und Ontogeneso des Kleinhirns. Folia Neuro-Biol. 20,1918. 15) 児玉作左衛 阴，小川鼎三：人体解剖医譜，中枢神経系 5 , 金原出 版, 1956 . 16) Lorente de Nó, R.: Augenmuskelreflexe beim Kamuchen und ihre Grundlagen. Ergebn. Physol., Biol. Chem. Exp. Pharmakol. 32. 73, 1931, 17) Lorente de Nó, R: Observations on nystagmus. Acta. Oto-laryn. 21, 416,1935. 
Lorente de Nó, $R$ : Vestibulo-ocular reflex arc. Arch. Nurol. \& Psychiat. 30, 246, 1933.

Leidler, R: Experimentelle Untersuchungen des Endigungsgebiet des Nervus vestibularis. Monatsch. f. Ohrenh. 47, 389, 1913. 20) Leidler, R.: Experimentelle Untersuchungen über das Endigungsgebiet des Nervus vestibularis. 2. Mitteilung. Neur. Inst. Univ. Wien, 21, 151, 1916.21 ) Marburg, $O$ : Zur Lokalization des Nystagmus. Neur. Zbl, 31 , 1366,1912、22) 松下英志：前庭神経核（䂺に「ダ イテルス」氏核及び三角核）揁伤により若引される腿球

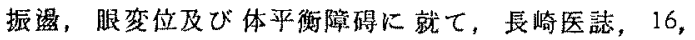
770, 1938. 23) Magoun, H.W.: Candal and cephalie influences of the brain stem reticular formation. Physiol Rev. 30. 459, 1950.

Montandon, P.: Functional correlations between the diencephalic nystagmogenic area (DNA) and the vestibular nystagmogenic area (VNA). Acta Oto-Laryng. suppl. 186, 1964.

25) Muskens.

L.J.J: Das supravestibuläre System. Amsterdam

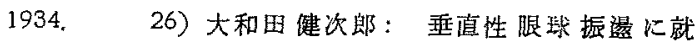

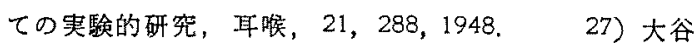
克己：家乘中权神経系の儌害と眼振，日新医学，38, 690, 1951. 28) 小川鼎三: 眐の解剖学, 南山堂, 1951. 29) Pompeiano, O,; Brodal, A.: SpinoVestibular fibers in the cat. An experimental study. Journ. Comp. Neurol 108, 353, 1957. 30) Pompeiano, $O$; Walberg, $F$ : Descending connections to the vestibular nuclei, An experimental study in the cat. Journ. Comp. Neurol. 108, 465, 1957. 31) Pompeiano, O.; Brodal, A: The origin of vestibulospinal fibers in the cat. Arch. Ital. Biol. 95, 166 , 1957. 32) Rasmussen, A.R.: Secondary vestibular tract in the cat. Journ, Comp. Neurol. 54, 143, 1932. 33) Spiegel, E.A.: Uber den Erregungszstand der medullären Zentren nach doppelseitigen Labyrint- hausschaltung. Pflüg. Arch. ges, Physiol 215, 106, 1927. 34) Spiegel, E.A.; Aronson, $L$; The intraction of cortical and labyrinthine impulse to vcular muscle movement. Am. J. physiol. 109, 693, 1934. 35) Spiegel, E.A.; Scala N.P.: Vertical nystagmus following lesion of the cerebellar vermis. Arch. Ophthalmol. 26, 661, 1941.

Taber, E: The cytoarchitecture of the brainstem of the cat. 1. Brainstem nuclei of cat. Journ. Comp. Neurol. 116, 27, 1961. 37) Teng, O: Shanzer, S.: Oculomotor pathways determined by electrolytic les ion brain stem. Am. J. Physiol 187, 636, 1956 . 38) Utsumi, S; Shindo, H, Yamanaka, Y; Electromyo-

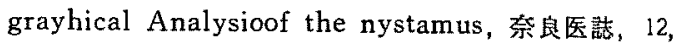
1090. 1961，39）高標宽之助：前庭神経中权核之迷走 神経背核との結合について，耳臨，26,125, 1931，40) 竹林弘: 眼振発現機锖亚びに治療に対する上丘の意義， 脳亡神経，13(10), 825, 1951， 41) Walzl, E.M: Projection of vestibular nerve to cerebral cortex of cat. Am. J. Physiol 159. 595, 1949. 42) Wagman, I.H.: Motor effects of stimulation of cerebrum and brainstem via chronically implanted electrodes. Trans. Am. Neurol. Ass, 160. 162. 1957.

和を終るに当り，御指導ならびに御校閲を賜 つた恩師石倉武堆漖授に染甚なる謝意を表わす とともに，組織解剖学的检索に関し愍第な御指 導を賜つた当大学第二解剖学益田栄教授，石井 朗夫学士はじ教室員各位，終始御指導御協力 いただいた当教室河村正三助教授，住田邦头学 士ならびに教室員各位に裂心より感謝いたしま t)

(本論本の要旨は，日本耳奥咽㬋科学会凰東 地方会第 408 会例会に抹いて発表した)。

（原称到着 $=$ 昭和 39.12 .17 日一急載） 
付図 1 No. 24（外翝神経核の高さ）

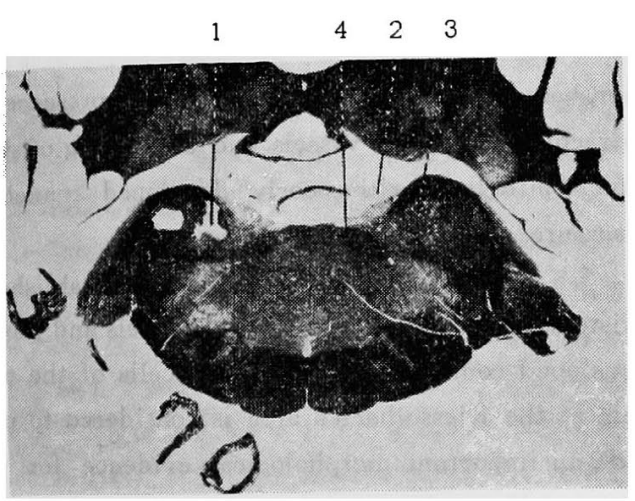

付図 3 No. 28 (竩面神経㤥の高さ)

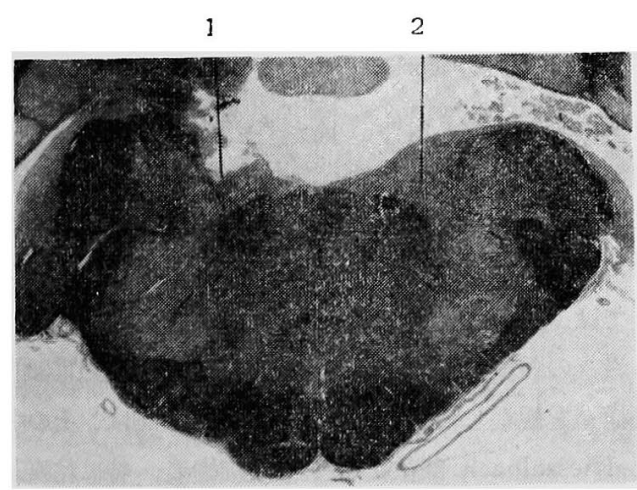

$1 ：$ 損傷部位
2：前庭神経内側核

3: 前庭神経外側核
付図 2 No. 26 (钼面神経核の高さ)

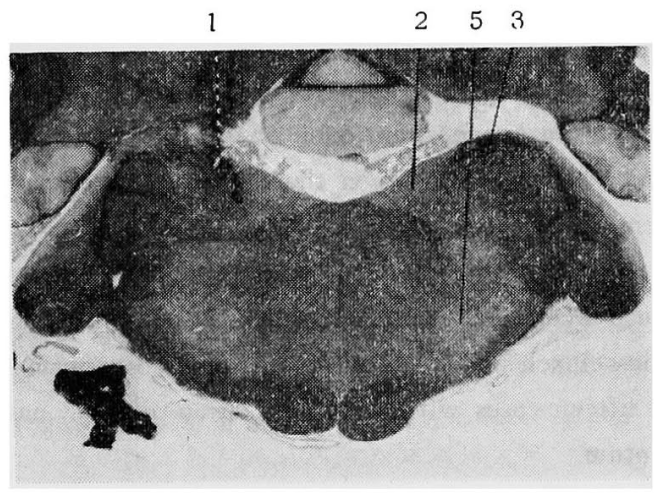

付図 4 No. 28 の損甥部位の強拡大 $(x 4)$

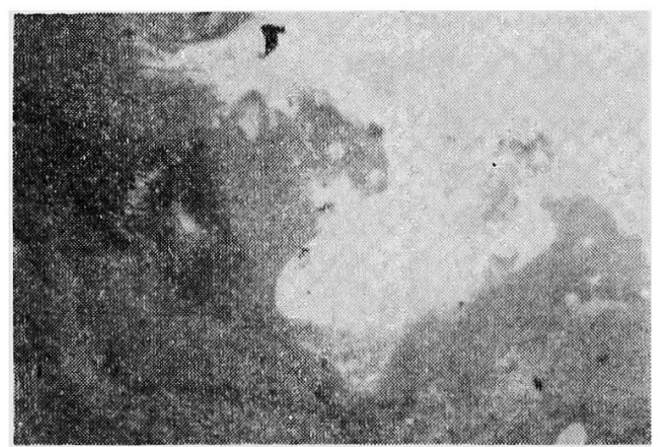

$4:$ 外旋神経核 5 : 顔面神経核 